\title{
Supplementary household water sources to augment potable municipal supply in South Africa
}

\author{
Nicole Nel', Heinz Erasmus Jacobs ${ }^{1}$, Carlo Loubser ${ }^{1}$ and Kobus (JA) Du Plessis ${ }^{1}$ \\ ${ }^{1}$ Department of Civil Engineering, Stellenbosch University, Private Bag X1, Matieland, 7602, South Africa
}

\begin{abstract}
This paper addresses on-site supplementary household water sources with a focus on groundwater abstraction, rainwater harvesting and greywater reuse as available non-potable water sources to residential consumers. An end-use model is presented and used to assess the theoretical impact of household water sources on potable water demand in formal residential areas. Reliable potable municipal supply to urban consumers via the water distribution system is typically linked to relatively low uptake of household water sources. However, stringent water restrictions in some large South African cities that prohibit outdoor use, and reports of intermittent water supply, have led to increased uptake of household sources in South Africa. This paper describes the legal position regarding such sources in South Africa, and describes an end-use model to assess the theoretical impact on water demand in formal residential areas. The model provides valuable strategic direction and indicates a significant theoretical reduction in potable municipal water demand of between $55 \%$ and $69 \%$ for relatively large properties when household sources are maximally utilised (when compared to exclusive unrestricted municipal use as a baseline). This load reduction on piped reticulation systems could be an advantage in order to augment municipal supply, but water service planning and demand management are complicated by the introduction, and possible future decommissioning, of any household water source. The extent of both positive and negative impacts of household water sources requires further research.
\end{abstract}

Keywords: household water use, alternative resources, water demand

\section{SUPPLEMENTARY WATER SOURCES}

\section{Rationale}

Recent stringent water restrictions in various municipalities in South Africa, as well as reports of intermittent water supply, have led to increased uptake of supplementary household water sources (HWS) in relatively affluent suburbs. Outdoor use of potable water is often targeted by demand management campaigns and even banned during serious water restrictions. The current water restrictions in Cape Town entail a ban on all use of municipal drinking-quality water for outside and non-essential purposes (City of Cape Town, 2017). However, outdoor residential environments have been found to be extremely important to homeowners (Blaine et al., 2012), also affecting residents' sense of social status or acceptance in the neighbourhood. Clayton (2007) found that gardening has important positive effects on individuals, as well as on the urban ecosystem. Also, a poorly maintained garden has been found to lower the potential monetary value of not only that property, but also neighbouring ones (Clayton, 2007). Homeowners with property in the market during water restrictions could fail to see outdoor water use as non-essential; the cost of water is rightly considered relatively low compared to even a small change in property value.

Consumers with suburban gardens are thus turning to supplementary water sources to meet garden irrigation demands, including rainwater (Beal et al., 2012; Mukheibir et al., 2014), groundwater (Wright and Jacobs, 2016; Botha, 2017) and greywater (Carden et al., 2017). Introduction of a HWS would increase the quantity of household supply, with the perception of improved reliability of household water supply. The impact of

To whom all correspondence should be addressed. 용 +27 21808 4059; e-mail: hejacobs@sun.ac.za Received 10 March 2017; accepted in revised form 24 August 2017 supplementary water sources on the potable water supply and demand in formal residential areas is poorly understood.

\section{Overview of supplementary household water sources}

A supplementary HWS is any water source that is available to a household (hh) to supplement potable supply from the water distribution system. The most common types of HWS, which form the focus of this paper, include groundwater abstraction, rainwater harvesting and greywater reuse. Milne (1979) reported almost 4 decades ago on these sources of 'free water' and described ways to collect, store, treat, and distribute the water, with examples of how it has been successfully reused for toilet flushing, garden irrigation, washing, bathing and even drinking.

Other alternative household sources include, for example: the use of water supplied via irrigation channels along streets, common in many towns in the Boland region of the Western Cape Province; the use of air conditioner condensate or geyser overflows; dehumidifiers; water abstracted directly from neighbouring mountain streams; stormwater use; importing bottled water from retail outlets for drinking purposes and importing non-potable water in relatively large containers for garden irrigation. Table 1 provides a summary of supplementary household water sources in the urban environment.

The available water from a HWS is commonly applied to meet garden irrigation (GI) demand, where water quality issues are often not of a high concern and the quality from the source is generally considered acceptable in view of the intended application (Botha, 2017). Application of greywater reuse as HWS for toilet flushing has been researched in the past (Grobicki and Cohen, 1999; Ilemobade et al., 2012). For many of the intended end-uses water can be reused directly without treatment (Milne, 1979), but issues regarding environmental pollution and community health (Govender et al., 2011) are becoming increasingly important, especially for greywater reuse (Carden et al., 2017). 


\begin{tabular}{|c|c|c|c|c|c|}
\hline \multicolumn{6}{|c|}{$\begin{array}{c}\text { TABLE } 1 \\
\text { Overview of supplementary household water sources }\end{array}$} \\
\hline \multirow[t]{2}{*}{ Type of HWS } & \multirow{2}{*}{$\begin{array}{l}\text { Previous } \\
\text { research }\end{array}$} & \multicolumn{4}{|c|}{ Comment based on earlier research } \\
\hline & & $\begin{array}{l}\text { Typical yield }(Y) \text { or } \\
\text { Flow rate }(Q) \text { per } \\
\text { household }\end{array}$ & $\begin{array}{l}\text { Source water } \\
\text { quality }\end{array}$ & Possible application & Advantages and disadvantages \\
\hline Groundwater & $\begin{array}{l}\text { Wright and } \\
\text { Jacobs } \\
(2016)\end{array}$ & $\begin{array}{l}\text { Relatively high yield } \\
0.1 \mathrm{~L} \cdot \mathrm{s}^{-1}<Q<1.0 \mathrm{~L} \cdot \mathrm{s}^{-1}\end{array}$ & $\begin{array}{l}\text { Normally non- } \\
\text { potable, but } \\
\text { depends on } \\
\text { aquifer }\end{array}$ & $\begin{array}{l}\text { Outdoor use and toilet } \\
\text { flushing; no storage } \\
\text { needed }\end{array}$ & $\begin{array}{l}\text { High yield possible, but not } \\
\text { guaranteed; very high capital } \\
\text { and high energy cost; possible } \\
\text { environmental impact (e.g., } \\
\text { lowering groundwater table) }\end{array}$ \\
\hline $\begin{array}{l}\text { Rainwater: not } \\
\text { internally } \\
\text { plumbed }\end{array}$ & $\begin{array}{l}\text { Dobrowksy } \\
\text { et al. (2014); } \\
\text { Mukheibir } \\
\text { et al. (2014); } \\
\text { Fisher-Jeffes } \\
\text { et al. (2017) }\end{array}$ & $\begin{array}{l}\text { Varies notably } \\
\text { Low summer yield } \\
\text { in winter rainfall } \\
\text { regions with } Y \approx 0 \\
\text { in peak summer } \\
\text { time }\end{array}$ & Non-potable & $\begin{array}{l}\text { Outdoor use, hand } \\
\text { washing of clothes, } \\
\text { house cleaning (e.g. } \\
\text { floors) }\end{array}$ & \multirow{2}{*}{$\begin{array}{l}\text { Yield is a function of rainfall, } \\
\text { storage and roof size; } \\
\text { potential mismatch between } \\
\text { seasonal rainfall and highest } \\
\text { demand; high capital cost; } \\
\text { possible environmental } \\
\text { impact (e.g., reduced urban } \\
\text { streamflow impacts natural } \\
\text { ecosystems) }\end{array}$} \\
\hline $\begin{array}{l}\text { Rainwater: } \\
\text { Internally } \\
\text { plumbed tanks }\end{array}$ & $\begin{array}{l}\text { Beal et al. } \\
(2012)\end{array}$ & $\begin{array}{l}\text { Varies notably }^{2} \\
\text { Queensland Australia. } \\
Y \text { varies from } \\
54-260 \mathrm{~L} \cdot \mathrm{hh}^{-1} \cdot \mathrm{d}^{-1} \text {, } \\
\text { with ave. } \\
137 \mathrm{~L} \cdot \mathrm{hh}^{-1} \cdot \mathrm{d}^{-1}\end{array}$ & Non-potable & $\begin{array}{l}\text { As above plus toilet } \\
\text { flushing and clothes } \\
\text { washing }\end{array}$ & \\
\hline Greywater $^{4}$ & $\begin{array}{l}\text { Christova- } \\
\text { Boal et } \\
\text { al. (1996); } \\
\text { Eriksson et } \\
\text { al. (2003); } \\
\text { WHO (2006) }\end{array}$ & \begin{tabular}{|l|} 
Reported $Y$ varies from \\
$218-346 \mathrm{~L} \cdot \mathrm{hh}^{-1} \cdot \mathrm{d}^{-1} ;$ \\
or about \\
$\pm 100 \mathrm{~L} \cdot \mathrm{c}^{-1} \cdot \mathrm{d}^{-1}$ \\
$($ Jacobs and Van \\
Staden, 2008)
\end{tabular} & $\begin{array}{l}\text { Non-potable, } \\
\text { relatively } \\
\text { poor quality } \\
\text { (Maimon et } \\
\text { al., 2010) }\end{array}$ & $\begin{array}{l}\text { Outdoor irrigation } \\
\text { (Carden et al., 2017); } \\
\text { toilet flush (Ilemobade } \\
\text { et al., 2012) }\end{array}$ & $\begin{array}{l}\text { Relatively constant yield; yield } \\
\text { reduces in line with indoor } \\
\text { water savings; relatively high } \\
\text { community health risk and } \\
\text { environmental risks; high } \\
\text { capital and energy cost if treated }\end{array}$ \\
\hline $\begin{array}{l}\text { Roadside } \\
\text { irrigation } \\
\text { channels }\end{array}$ & N/A & $\begin{array}{l}\text { Depends on the } \\
\text { property 'water } \\
\text { rights' }\end{array}$ & $\begin{array}{l}\text { Non-potable, } \\
\text { poor quality }\end{array}$ & $\begin{array}{l}\text { Flood irrigation methods } \\
\text { (incl. backyard vegetable } \\
\text { gardens and urban } \\
\text { agriculture) }\end{array}$ & \multirow[t]{2}{*}{$\begin{array}{l}\text { Not common in urban areas; } \\
\text { limited to rural towns; use } \\
\text { is normally limited to flood } \\
\text { irrigation }\end{array}$} \\
\hline $\begin{array}{l}\text { Abstraction from } \\
\text { nearby rivers or } \\
\text { streams }\end{array}$ & N/A & $\begin{array}{l}\text { Depends on the } \\
\text { property 'water } \\
\text { rights' }\end{array}$ & $\begin{array}{l}\text { Non-potable } \\
\text { (assuming } \\
\text { urban } \\
\text { streams) }\end{array}$ & Outdoor use & \\
\hline $\begin{array}{l}\text { Imported water } \\
\text { (potable bottled } \\
\text { water) }\end{array}$ & Doria (2006) & $\begin{array}{l}\text { Typically limited } \\
\text { to potable } \\
\text { consumption } \\
< \pm 2.0 \mathrm{~L} \cdot \mathrm{c}^{-1} \cdot \mathrm{d}^{-1} \\
\end{array}$ & Potable & Human consumption & $\begin{array}{l}\text { High carbon footprint; } \\
\text { exceptionally low yield; has } \\
\text { to be physically imported; } \\
\text { high cost }\end{array}$ \\
\hline $\begin{array}{l}\text { Containerised } \\
\text { imported water } \\
\text { (non-potable) }\end{array}$ & $\mathrm{N} / \mathrm{A}$ & $\begin{array}{l}\text { Delivered by } \\
\text { vendors via road in } \\
\text { containers (typical } \\
\text { during serious } \\
\text { water restrictions) }\end{array}$ & Non-potable & Outdoor use & $\begin{array}{l}\text { May be illegal to sell water in } \\
\text { this way to other consumers; } \\
\text { expensive; has to be physically } \\
\text { imported }\end{array}$ \\
\hline $\begin{array}{l}\text { Air conditioner } \\
\text { condensate }\end{array}$ & N/A & $\begin{array}{l}\text { Relatively low } Y \text { for } \\
\text { households }\end{array}$ & $\mathrm{N} / \mathrm{A}$ & $\begin{array}{l}\text { Outdoor - at point of } \\
\text { overflow }\end{array}$ & $\begin{array}{r}\text { Limited to air-conditioned } \\
\text { spaces; exceptionally low yield }\end{array}$ \\
\hline $\begin{array}{l}\text { Atmospheric } \\
\text { water generators } \\
\text { (dehumidifiers) }\end{array}$ & N/A & $32 \mathrm{~L} \cdot \mathrm{d}^{-1}$ to $100 \mathrm{~L} \cdot \mathrm{d}^{-1}$ & Potable & Indoor; potable & $\begin{array}{l}\text { High capital and high energy } \\
\text { cost }\end{array}$ \\
\hline $\begin{array}{l}\text { Geyser (hot } \\
\text { water) overflow }\end{array}$ & N/A & $\begin{array}{l}\begin{array}{l}\text { Relatively low } Y \text { for } \\
\text { households }\end{array} \\
\end{array}$ & $\mathrm{N} / \mathrm{A}$ & \begin{tabular}{|l|}
$\begin{array}{l}\text { Outdoor - at point of } \\
\text { overflow }\end{array}$ \\
\end{tabular} & $\begin{array}{l}\text { Emergency overflow only; very } \\
\text { low yield }\end{array}$ \\
\hline $\begin{array}{l}\text { Stormwater } \\
\text { (excludes } \\
\text { rainwater } \\
\text { harvesting) }\end{array}$ & $\begin{array}{l}\text { Fisher-Jeffes } \\
\text { et al. (2017) }\end{array}$ & \multicolumn{4}{|c|}{$\begin{array}{l}\text { Possible future application: urban stormwater is not typically abstracted from the stormwater system } \\
\text { beyond the property boundary for household use, but could be feasible in exceptional cases }\end{array}$} \\
\hline Seawater & N/A & \multicolumn{4}{|c|}{$\begin{array}{l}\text { Possible future application: coastal properties have access to the sea and could potentially obtain } \\
\text { rights to abstract and treat seawater }\end{array}$} \\
\hline
\end{tabular}

${ }^{1}$ Depends on the abstraction method, infrastructure (e.g. pump capacity) and geohydrology of the consumer's plot

${ }^{2}$ Critical assumptions relate to tank size, roof collection size, and system components or configuration; parameters that vary notably from one region to another and one house to the next

${ }^{3}$ Internally plumbed rainwater tanks (IPT) substitute mains water in the laundry and toilets and are ideally installed during house construction ${ }^{4}$ Maimon et al. (2010) note that the use of untreated greywater is not recommended due to associated risks, even for single households 


\section{Impacts of a HWS on water services}

The application of a HWS has an impact on all municipal water infrastructure:

- An apparent load reduction is experienced on the potable water distribution system with reduced annual average use, reduced monthly use in peak periods, and reduced peak flows for any HWS used

- For greywater reuse particularly, an apparent volumetric load reduction is experienced in the sewer system, with reduced sewage flow rates and increased pollutant concentrations due to the lower flow rate

- Rainwater harvesting and storage reduces the total rainwater running off to the stormwater system, and on-site storage tanks may attenuate the hydrograph peak in the stormwater system during small storm events thus inducing an apparent - albeit relatively insignificant - load reduction in the stormwater system (Fisher-Jeffes et al., 2017)

The impacts noted above bring advantages and disadvantages in each case. If managed properly a HWS could hold numerous advantages from the viewpoint of the homeowner and service provider. In contrast, however, various concerns have been noted with introduction of a HWS. One of the most notable impacts of a HWS is reduced consumption, and reduced consumer billing, coupled with reduced income to the service provider. Consumers who can afford a HWS are often those who use water in the relatively expensive tariff blocks for outdoor irrigation (assuming a block tariff structure), thus contributing notably to the service provider's coffers when using potable water for garden irrigation. Introducing a HWS reduces the generated municipal income from higher tariff blocks. Consumers with a HWS are typically in a position to pay water bills (non-payment is a notable problem in developing countries, especially in lower income areas). Decreased income from water sales due to uptake of a HWS is often not appreciated by decision makers, nor is the topic well researched. The following aspects also require further investigation:

- Guidelines for estimating water use are often based on analyses of data from consumer water meters, which would no longer accurately reflect the actual total water needs of residential consumers after introduction of a HWS. What would happen to the potable water demand if the HWS were decommissioned in the future, with supply drawn from the piped system again?

- Reduced sewer flows could lead to clogging of sewers and higher pollutant loads at the treatment plant; and reduced stormwater runoff could lead to drainage systems clogging due to insufficient flow rates during peak events, with minimum flow velocity needed to flush the system.

\section{Groundwater}

Groundwater is abstracted via one of various 'structures' delivering it from under the ground surface to above the surface, including, for example, a borehole, well point, shallow well or even a fountain or spring. The term groundwater abstraction point (GAP) is adopted in this paper from work by Wright and Jacobs (2016), and describes abstraction of water from underground for terrestrial application, typically garden irrigation. Although research into the yield of GAPs is limited, it is widely accepted that the flow rates and yields from different GAPS vary spatially and temporally; for example, some GAPS (especially shallow well-points) may 'dry up' as the groundwater table drops below the abstraction point during a dry period.

\section{Greywater reuse}

Greywater is a term often used to describe sullage. Sullage is defined in the Oxford dictionary as, 'waste from household sinks, showers and baths, but not toilets'. Some authors, however, note that greywater excludes wastewater from kitchen sinks. According to Zeisel and Nolde (1995), black water includes wastewater from the toilet, dish washing and food preparation. Kreysig (1996) defined greywater as effluent from washbasins, showers and baths, and could include clothes and washing machine water. A more detailed classification is provided by Carden et al. (2017), considering 'light' (Class I and Class II) and 'dark' (Class III) greywater - noting also that the end-use source of greywater should not be used as the sole determinant in classifying greywater into the different classes.

Greywater represents a notable water source that would otherwise be wasted. Greywater reuse has the potential to alleviate the demand on potable water resources as well as reduce the inflow to wastewater treatment works. Furthermore greywater is also a potential source of nutrients for plant growth, particularly for users who cannot afford fertiliser, and the soapy nature of greywater means that under some conditions it may act as a pest-repellent (Rodda et al., 2011). Greywater is, however, inherently variable in quality and as is most likely to be applied on a scale where quality monitoring is not feasible (Rodda et al., 2011). A range of contaminants may cause disease and have a negative impact on the environment.

\section{Rainwater}

The term rainwater harvesting implies the intentional diversion of rainwater from roofs to a storage tank. The definition does not include indirect application of rainwater, even if intentional, if it is not stored prior to application. In other words, the (possibly intentional) diversion of gutters into a garden bed would not constitute rainwater harvesting as per this definition. A rainwater harvesting system consists of a number of integrated system components, including a catchment area, a storage vessel and a distribution system. External factors, such as climatic conditions, rainfall patterns and the end uses of rainwater, could drastically influence the viability of domestic rainwater harvesting systems (Fisher-Jeffes et al., 2017). Dobrowksy et al. (2014) noted that acceptance of rainwater as a source and training of consumers to maintain and use the tank system optimally was essential to ensure that social development projects involving rainwater use would be sustainable. Mukheibir et al. (2014) revealed a data gap in knowledge about rainwater tank functionality and the performance of existing rainwater tank systems, noting also that ongoing maintenance of the rainwater system is essential to ensure continued substitution of potable water supplied via the distribution system.

\section{METHODOLOGY}

National and international literature were reviewed to gain an overview on HWS, including application, impact and the various types of sources. The legal framework relating to the most notable HWS use was then determined through a survey of relevant legislation. The residential end-use model (REUM), initially presented by Jacobs and Haarhoff (2004a), was used in this study to assess the theoretical impact of supplementary HWS on potable water demand. The initial Microsoft Excel 
based model was extended to include HWS options, with a focus on garden irrigation as an end-use. Various parameters for the modelling exercise were investigated and assumptions were made to describe the hypothetical household investigated.

\section{LEGAL ASPECTS}

\section{The right to use water}

The theoretical impact of HWS on potable water demand from the municipal supply is investigated in this paper, but of first importance is to assess whether the use of water from a HWS is permitted by law. The legal status regarding the use of HWS by individual homeowners is not well delineated. At household level in serviced areas consumers obtain water from a Water Service Provider (WSP), which is normally the local municipality. The legal position is contained in the National Water Act (NWA) (Act No. 36 of 1998) and to a limited extent also the Water Services Act (WSA) (Act No. 108 of 1997).

\section{South African legislation - National Water Act}

The main objective of the South African National Water Act (Act No. 36 of 1998) is to make provision for the management of water resources in South Africa through relevant management structures (RSA, 1998). A HWS could be deemed a water resource. Of specific interest to the household user is the identification of what is considered as permissible use and the procedure associated with this use. It is considered essential to at least obtain some basic knowledge as to the legal implications concerned where a homeowner uses groundwater, rainwater or greywater on the particular property where the water is captured. Carden et al. (2017 p. 3-7) point out that, 'some local authorities have introduced policies and by-laws which provide guidance relevant to the management and use of greywater for irrigation, but the status remains in doubt as long as the status of greywater use in terms of the national legislation is not clarified.'

Section 21 of the National Water Act (Act No.36 of 1998) states that, among others, the 'taking of water from a resource' constitutes a water use (RSA, 1998). In general terms, a licence is required for any water use and the procedures are dealt with in the Act. Section 26 of the Act also empowers the Minister to make regulations to enforce the registration of all water uses (RSA, 1998). These regulations (Regulation 1352 published in Government Gazette No 20606, 12 November 1999) effectively require the registration of all water use activities within a specific time frame. This could imply that homeowners need to register HWS use with the DWS; however, water uses exempt from the registration process are provided in section 10 of the Regulation and include:

- Schedule 1 use

- Those not required in terms of a general authorisation issued

- Water obtained from a bulk water supplier or other management structure

A number of situations exist where water can be used without a licence, as stipulated in Section 22 of the Act (RSA, 1998):

A person may only use water -

(a) without a license

(i) if that water use is permissible under Schedule 1;

(ii) if that water use is permissible as a continuation of an existing lawful use; or

(iii) if that water use is permissible in terms of a general authorisation issued under section 39.

With reference to section 22 above, Schedule 1 water is defined in the Act as a user who is to (RSA, 1998): (a) take water for reasonable domestic use in that person's household, directly from any water resource to which that person has lawful access;

(b) take water for use on land owned or occupied by that person, for

(i) reasonable domestic use;

(ii) small gardening not for commercial purposes; and

(iii) the watering of animals (excluding feedlots) which graze on that land within the grazing capacity of that land, from any water resource which is situated on or forms a boundary of that land, if the use is not excessive in relation to the capacity of the water resource and the needs of other users;

(c) store and use runoff water from a roof. Most household water uses could be considered Schedule 1 use. Rainwater from roofs, and boreholes for domestic purposes as stated above, could therefore be used without a licence by the consumer on the property where the HWS is located. Water from a HWS may not be sold to other consumers without a licence, because sale of water would constitute commercial activity (and would not be deemed Schedule 1 use). It is, however, still a requirement to ascertain whether a particular municipality could enforce registration of HWS sources in its area of jurisdiction via local by-laws.

An existing use, as is the case of a possible water right registered on an owner's title deed, does not need to go through an application for a licence process but can be continued until a verification or renewal of the licence is requested by the authority (for example property water rights to an irrigation channel running through town). In most cases the water use from these types of systems has been dealt with through the registration process by the responsible municipality or other relevant associated water management body. The registration of an existing use is compulsory in terms of section 151(1)(g) of the Act, stating that (RSA,1998):

(1) No person may

(g) fail to register an existing lawful water use when required by a responsible authority to do so;

The issuing of a licence will raise critical questions pertaining to the water use, such as whether the existing use is in fact a beneficial use. The issuing of a licence will depend on these evaluation criteria and might influence the final volume of water for which a licence will be issued. Where no licence is required according to section 22 , a general authorisation would be issued, regulating the water use in specific areas. These authorisations stipulate the quantities of water that can be used in each area without a licence, but the use must still be registered and the final issuing of a licence will once again be subject to a number of critical evaluation criteria.

\section{Water Services Act}

The main objectives of the WSA are described in section 2 of the Act and include (RSA, 1997): 'The right of access to basic water supply and the right to basic sanitation necessary to secure sufficient water and an environment not harmful to human health or well-being...'

This right is further emphasised in section 3 of the Act and 'basic water supply' is also defined in the Act as (RSA, 1997): '...the prescribed minimum standard of water supply services necessary for the reliable supply of a sufficient quantity and quality of water to households, including informal households, to support life and personal hygiene...' 
In subsequent policy documents the Department of Water and Sanitation (RSA, 2001) has defined the minimum basic supply as $25 \mathrm{~L} \cdot \mathrm{c}^{-1} \cdot \mathrm{d}^{-1}$. It is expected from each South African municipality to define these values in the Water Services Development Plan, which forms part of the municipal Integrated Development Plan. These minimum standards can be used in the evaluation of what constitutes a domestic use allowed for in the South African National Water Act.

\section{The 'legal rights' of a homeowner to a HWS}

In view of the above, the requirement for the registration of boreholes or the use of any 'personal' household water source by an individual within the municipal area is not dealt with directly in the NWA or the WSA. However, the use of a HWS could be regulated through the issuing of appropriate by-laws by a specific municipality, thus enabling the authority to apply good water governance principals. In summary:

- The use of any HWS for domestic purposes on the consumer's own property in a serviced area could be deemed 'legal' in the general case and no registration of the particular use is required

Unless:

- A municipality has followed the necessary procedures by which by-laws have been put in place, thus regulating the registration of such use - in such a case a homeowner may be required to register, with potential consequences should the homeowner fail to comply.

\section{CONCEPTUAL MODEL DESCRIPTION}

Once the legal position of the consumer had been outlined, the theoretical impact of HWS on water demand from the municipal supply was rationally assessed by means of an enduse model. The point of departure was to consider the case of serious water restrictions where outdoor use is banned: any consumer with access to a HWS would thus attempt to maximise use from the HWS, thus minimising the draw from the potable distribution system. The impact of the HWS on volumetric supply was investigated by means of an end-use model. The model is presented schematically in Fig. 1, showing the consumer water meter $(\mathrm{M})$, and typical indoor and outdoor end-uses. The schematic depicts an end-use model similar to REUM.

Each of these end-uses can be considered independently, keeping in mind that each end-use could be supplied from a different water source, including one or more supplementary HWS. The possible supply sources and waste sinks for a particular end-use should be considered integrally, as presented in Fig. 2. This study focused on households where potable water as primary water source is supplied from the water distribution system, and indoor use is wasted to the sewer system (bold outlines in Fig. 2). Reused greywater would typically be applied at a different end-use to the one where the greywater was generated. If applied indoors, the wasted reused greywater

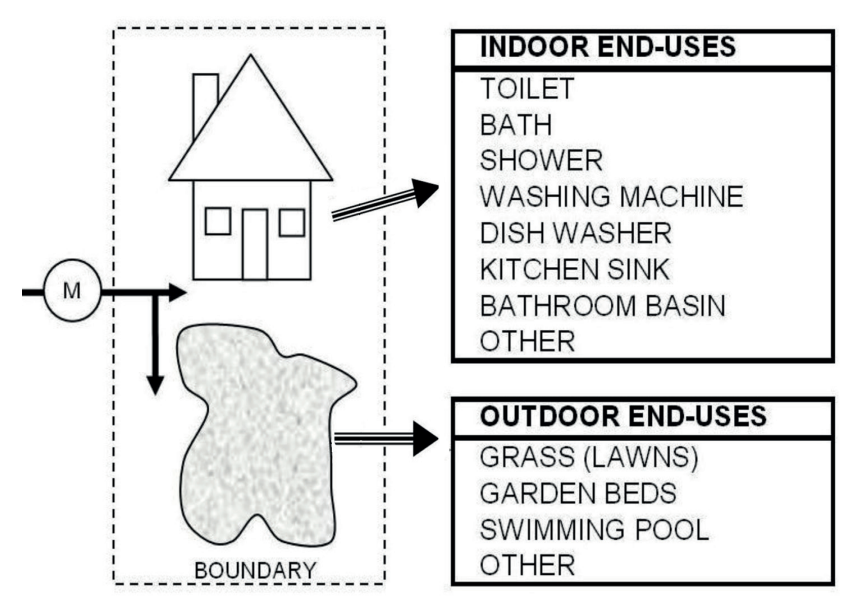

Figure 1

Schematic presentation of end-use model and end-uses

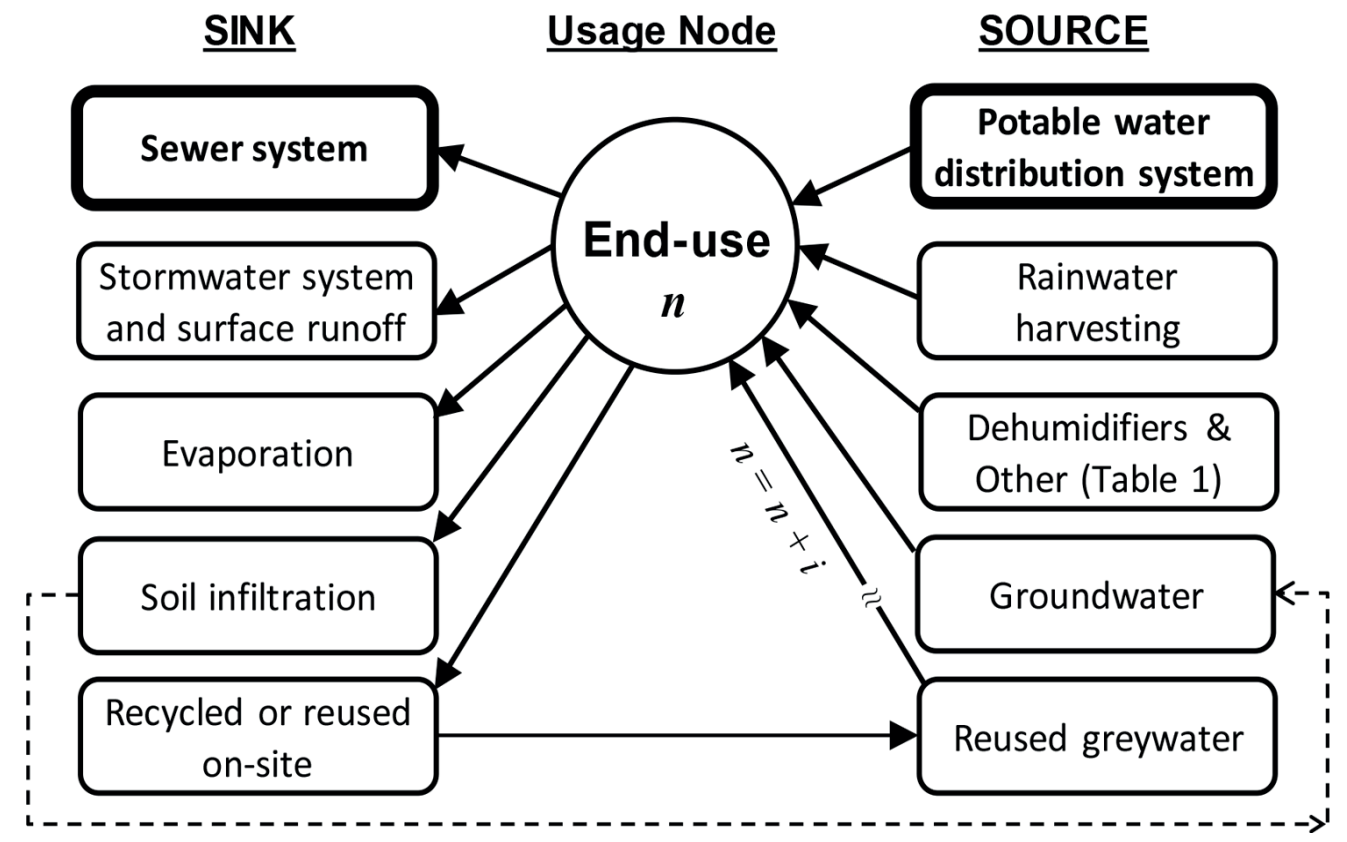

Figure 2

Schematic presentation of water sources and sinks for end-usen 
should drain away to the sewer system. Water used outdoors drains to the stormwater system, evaporates, or percolates into the soil. From the perspective of HWS application, the most notable end-use, $n$, would be garden irrigation (grass and garden beds), where non-potable application and greywater reuse is deemed feasible in terms of quality, although not necessarily financially viable (Fisher-Jeffes et al., 2017).

\section{END-USE MODELLING}

\section{REUM}

An add-on was developed to incorporate HWS to an end-use model reported on by Jacobs and Haarhoff (2004a). The residential enduse model named REUM was selected for this investigation due to its availability and open-source code in an MS Excel environment. REUM was used as a basis for the research in this study by extending the initial e-model to include HWS options.

Only garden irrigation was considered in this study, meaning that some of the HWS listed in Table 1 are not directly relevant to further analysis (for example, bottled water or dehumidifiers). The focus in terms of end-uses was on garden irrigation, because garden irrigation was considered to be the primary application point for water from a HWS. Only in exceptional cases or as part of research projects could information be obtained where homeowners applied HWS for other end-uses, including rainwater for clothes washing (Dobrowksy et al., 2014) and greywater for toilet flushing (Ilemobade et al., 2012). Future research could extend the analyses to include indoor use, such as toilet flushing or clothes washing with non-potable water.

\section{Lawn water demand as end-use}

Lawn water demand is described mathematically in the end-use model by a number of different parameters, including weather variables (rainfall, etc.). The theoretical change in a specific property's water use and wastewater flow could be evaluated by modifying only selected parameters in REUM, such as the weather variables, to model a similar property in different areas of the country. Garden irrigation is the main end-use resulting in geographic significance, because the water requirement is dependent on weather variables.

In this study, where the focus is on alternative water sources, the end-use model is used to predict the impact on the total household water demand if a HWS were used on the property. Modelling a HWS in REUM is possible by adjusting the parameter $f$, which describes how much of the theoretical garden water demand is supplied from the municipal supply system. In order to model garden irrigation, four end-uses were identified that are impacted by evaporation. These include three vegetation types and the pool. Of these, the lawn is the most significant in terms of the total volume used (Jacobs and Haarhoff 2004b) and also the most likely to be irrigated by water from a HWS.

\section{Description of the model and modelling process}

In REUM outdoor demand is modelled as different end-uses, including garden irrigation (for three different vegetation types) and pool evaporation (Jacobs and Haarhoff, 2004a). Garden irrigation requirements depend on factors influencing vegetation growth, including rainfall, run-off, infiltration, rootzone storage and evaporation. Garden water irrigation is closely related to moisture deficit, or potential evapotranspiration minus effective rainfall (Makwiza et al., 2017). Johnson (1987) also confirmed this in South Africa. A common method for calculation of evapotranspiration (ET), also presented by Green (1985), assumes that over a given period ET is directly proportional to pan evaporation, $p$. In other words, ET $=(k p)$, where $k$ is the empirical constant of proportionality known as the crop factor. Evaporation from a pool surface is also calculated by means of the same equation, but $k$ would represent the evaporation factor for the pool surface in this case.

Effective rainfall represents that portion of the rainfall that penetrates the soil and thus has an effect in reducing the water demand of plants. Various methods exist to estimate effective rainfall. In all cases the measured monthly rainfall, $R$ (in $\mathrm{mm} \cdot \mathrm{month}^{-1}$ ), is the independent variable. The equation used in REUM to model the effective rainfall, $r$, originates from work by Linsley and Franzini (1979) and is reported on by Johnson (1987), who used this method to analyse the garden water demand in Port Elizabeth.

The equation states that rainfall less than $25 \mathrm{~mm}$ is $100 \%$ effective and then decreases linearly until a point where rainfall in excess of $152 \mathrm{~mm}$ has an effectiveness of only $89 \mathrm{~mm}$ :

$$
r=\left[\begin{array}{ll}
R & (R<25 \mathrm{~mm}) \\
(0,504) \cdot R+12,4 & (25 \leq R<152) \\
89,0 & (R \geq 152)
\end{array}\right]
$$

In view of the above, the average monthly daily demand (AMDD) for an outdoor end-use $e$, and month $m$, is modelled by the following equation (Jacobs and Haarhoff, 2004a):

$$
A M D D_{o, m, e}=\left(f_{m, e} \cdot s_{m, e}\right) \cdot \frac{\left(k_{m, e} \cdot p_{m, e}\right)-r_{m, e}}{d a y s_{m}}
$$

where subscript $o$ denotes outdoor, $m$ denotes month, and $e$ denotes the end-use for the outdoor equation and days ${ }_{m}$ refers to the number of days in a month. A value of 30.44 (the average number of days in a month) can be used to obtain average values, as was done in this study.

The equation for estimating outdoor use shows a relatively simple linear relationship between the explanatory variables and the water demand. In other words, a linear result would be expected when adjusting the factor $f$ for analysis, as per this study.

The AMDD for all outdoor end-uses $\left(A M D D_{o, m}\right.$ in $\left.\mathrm{L} \cdot \mathrm{hh}^{-1} \cdot \mathrm{d}^{-1}\right)$, the average annual daily demand $(A A D D)$ for any specific outdoor end-use $e\left(A A D D_{o, e}\right.$ in $\left.\mathrm{L} \cdot \mathrm{hh}^{-1} \cdot \mathrm{d}^{-1}\right)$, and the AADD for all outdoor end-uses combined $\left(A A D D_{0}\right.$ in $\left.\mathrm{L} \cdot \mathrm{hh}^{-1} \cdot \mathrm{d}^{-1}\right)$ are obtained by summing over the 12 months, as reported by Jacobs and Haarhoff (2004a):

$$
\begin{aligned}
& A M D D_{o, m}=\sum_{e=1}^{12} A M D D_{o, m, e} \\
& A A D D_{o, e}=\sum_{m=1}^{4} A M D D_{o, m, e} / 12 \\
& A A D D_{o}=\sum_{m=1}^{12} \sum_{e=1}^{4} A M D D_{o, m, e} / 12
\end{aligned}
$$

This end-use model, combined with the additional water supply from the HWS, was used to analyse the effect of a HWS at relatively low-density properties in Cape Town, but not taking into account the actual availability of HWS in that particular region. In other words, the result is a maximum potential (theoretical) reduction due to the use of a HWS. It does not matter from a modelling perspective which type 
of HWS source is used, because application is for outdoor irrigation, which would be valid for all three types of HWS under consideration.

\section{Garden irrigation factor}

The garden irrigation factor $f$ is a theoretical parameter in the end-use model to describe and analyse garden water irrigation. Parameter $f$ can be adjusted to represent changes in the efficiency of the irrigation system, the habits of consumers regarding over- or under-irrigation of vegetation or, as is the case here, to also model water use from alternative water sources. Parameter $f$ would not allow for modelling water use from a HWS indoors, however.

The value of $f$ could be considered to vary between zero and some higher value. If the factor were set equal to zero $(f=0)$ the implication is that the garden is not irrigated at all, or the garden is irrigated entirely with water from the HWS (no irrigation water is used from the water distribution system). On the other hand, if the factor is set to unity $(f=1)$ at the property, it tells the analyst that the garden irrigation volume is equal to the theoretical estimate; in other words, the theoretical ideal water requirement would be supplied from the potable water distribution system. The upper value of $f$ is determined by over-irrigation of vegetation or wastage due to inefficient irrigation systems. No upper value for $f$ has yet been reported; clearly a field for further research.

\section{RESULTS}

\section{Theoretical saving for various scenarios}

For the purpose of this modelling exercise, which is essentially a comparison between different HWS scenarios, it is not critical to select a 'correct' value for parameter $f$. The parameter is in fact adjusted between realistic boundaries (say 0 to 1 ) in order to theoretically assess the impact of HWS use on the potable municipal supply system. In the modelling exercise parameter $f$ is used to describe:

- The fraction of all properties in a particular area that make use of HWS

- The fraction of the total garden irrigation demand met by the HWS

For this modelling exercise the following parameters were investigated and assumptions were made to describe the hypothetical household subsequently investigated:

- The household size is 3 people per household, but the precise value is not important in this work because the parameter for household size does not affect garden irrigation; the only implication would be when considering the percentage of water used for garden irrigation in relation to the total (or indoor use), for example; the selection of 3 people per household is considered to be realistic for the property size range under investigation at the relatively coarse resolution of this study

- The total property area is $1000 \mathrm{~m}^{2}$

- In all cases $25 \%$ of the area is considered to be covered by irrigated lawn and $10 \%$ by garden beds; combined, these vegetation types make up the garden irrigation

- Other model input parameters are set to the values reported for Cape Town in previous research (Jacobs and Haarhoff, 2004b)

The results of the analysis are summarised in Table 2 and Fig. 3. With reference to these results for a property of $1000 \mathrm{~m}^{2}$ if $100 \%$ of the consumers were to use a HWS source, or combination thereof, to meet $100 \%$ of the garden irrigation, a theoretical reduction of $55 \%$ in municipal water use could be achieved compared to the baseline value. The baseline was the normal unrestricted demand with exclusive municipal supply via the potable system. The $100 \%$ uptake is considered unlikely and is presented as the upper limit. At the other extreme, if none of the consumers were to have access to a HWS then clearly $0 \%$ of the outdoor irrigation would be met from the HWS, and $0 \%$ reduction would be achieved, so all water would be supplied from the potable distribution system.

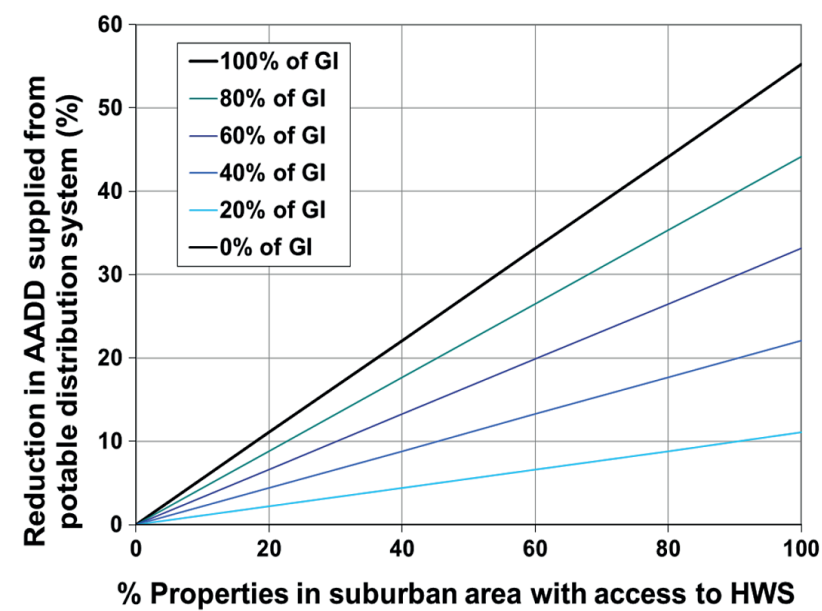

Figure 3

Theoretical saving potential for different application scenarios

\begin{tabular}{|c|c|c|c|c|c|c|}
\hline \multicolumn{7}{|c|}{$\begin{array}{c}\text { TABLE } 2 \\
\text { Theoretical saving potential for different scenarios }\end{array}$} \\
\hline \multicolumn{7}{|c|}{ Theoretical potable AADD-reduction for different HWS application scenatios } \\
\hline \multirow{2}{*}{$\begin{array}{l}\% \text { of properties in } \\
\text { area with access } \\
\text { to HWS }\end{array}$} & \multicolumn{6}{|c|}{ \% of garden irrigation (GI) demand met by HWS } \\
\hline & 0 & 20 & 40 & 60 & 80 & 100 \\
\hline 0 & 0 & 0 & 0 & 0 & 0 & 0 \\
\hline 20 & 0 & 2 & 4 & 7 & 9 & 11 \\
\hline 40 & 0 & 4 & 9 & 13 & 18 & 22 \\
\hline 60 & 0 & 7 & 13 & 20 & 27 & 33 \\
\hline 80 & 0 & 9 & 18 & 27 & 35 & 44 \\
\hline 100 & 0 & 11 & 22 & 33 & 44 & 55 \\
\hline
\end{tabular}




\section{Theoretical garden irrigation demand}

Referring to the previous section, it is necessary to determine what percentage of the garden irrigation could typically be supplied by the HWS source. When considering the yield, a sufficient volume from the HWS is needed to meet not only the average annual garden irrigation demand, but the peak irrigation demand (peak summer day), which is a greater concern. The peak day demand could be estimated by the end-use model. The model and limited tests at the Stellenbosch University campus during summer show that the theoretical lawn water requirement is $\pm 5 \mathrm{~L} \cdot \mathrm{m}^{-2}$ on a typical hot summer's day, with maximum temperatures at $\pm 35^{\circ} \mathrm{C}$ and no cloud cover. Garden beds were assumed to have the same demand for modelling purposes. For the $1000 \mathrm{~m}^{2}$ hypothetical property described above this would equate to a peak garden irrigation demand of $\pm 1750 \mathrm{~L} \cdot \mathrm{d}^{-1}$, presuming $25 \%$ coverage by lawn and $10 \%$ garden beds. Although lawns could be stressed (yet survive) with less water, the 'ideal' requirement was used in the analysis.

Using the stochastic end-use model for groundwater use developed by Botha (2017), which involved case study data from 10 homes in Cape Town with garden boreholes, it was found that the average garden irrigation peak of $996 \mathrm{~L} \cdot \mathrm{d}^{-1}$ could be met $\pm 96 \%$ of the time by the GAPs; also, groundwater supply would meet the $90^{\text {th }}$ percentile of garden irrigation peak demand $\left(1954 \mathrm{~L} \cdot \mathrm{d}^{-1}\right)$ with a certainty of $\pm 70 \%$. Groundwater yield is thus considered sufficient to meet garden irrigation at a typical suburban property.

Rainwater supply is often insufficient in view of garden irrigation in the Western Cape, due to relatively low summer rainfall, high irrigation demand, and limited size of rainwater tanks at residential homes. Fisher-Jeffes et al. (2017) confirmed that rainwater use, in the Western Cape study area investigated by the team, was not financially viable and underlined the need for future research to better understand the viability of rainwater harvesting in different climatic regions of South Africa.

Also, the available yield from greywater is limited to how much water is used for the bath, shower and washing machine indoors. Further research is needed to link greywater generation to water conservation. Conservation of water at the bath, shower and washing machine is likely to reduce greywater yield from the same home, because the end-use event volume directly generates greywater for re-supply.

For users with access to groundwater the ' $100 \%$ of garden irrigation' curve from Fig. 3 could be used, neglecting all the other curves that would apply if the yield were insufficient to meet the garden irrigation demand (e.g., those curves would apply for rainwater harvesting and greywater reuse in the absence of a groundwater source). The analyses from this point on focused on the case where $100 \%$ of the garden irrigation could be supplied from the HWS, because (i) a consumer clearly has a 'right' to use a HWS and also, (ii) the yield from a combination of HWS could meet the total garden irrigation demand, and (iii) in order to evaluate the maximum impact on the potable distribution system the maximum draw from the HWS should be considered as first priority.

\section{Results: Meeting $100 \%$ of garden irrigation demand}

The model was used to re-analyse the case where the HWS source would consistently meet $100 \%$ of the demand. Two additional property sizes were added to provide estimates of potential savings for a $1500 \mathrm{~m}^{2}$ and $2000 \mathrm{~m}^{2}$ property. Since the result is linear it was considered appropriate to provide two additional curves. The results are shown in Fig. 4, with the $y$-axis presenting the AADD supplied from the potable distribution system.

From Fig. 4 it is clear that all three lines converge to a point at about $650 \mathrm{~L} \cdot \mathrm{d}^{-1}$ (about $20 \mathrm{~kL}$ per month, or $217 \mathrm{~L} \cdot \mathrm{c}^{-1} \cdot \mathrm{d}^{-1}$ ), that is representative of the modelled typical indoor use only for the hypothetical 3-person household analysed. The maximum reduction is for a $2000 \mathrm{~m}^{2}$ property where the AADD would reduce from $2.1 \mathrm{~kL} \cdot \mathrm{d}^{-1}\left(2100 \mathrm{~L} \cdot \mathrm{d}^{-1}\right)$ to $0.65 \mathrm{~kL} \cdot \mathrm{d}^{-1}\left(650 \mathrm{~L} \cdot \mathrm{d}^{-1}\right)$, resulting in a reduction of almost $69 \%$ in potable supply when a HWS is used. The reduction was earlier noted to be $55 \%$ for a $1000 \mathrm{~m}^{2}$ property. The question remains as to what fraction of users would be likely to commission and sustain supply from a HWS and also to what extent garden irrigation could be met.

\section{The impact on water services planning}

Implementation of a HWS significantly complicates water demand management regarding the particular consumer, because water use from any HWS is typically unmetered and the supply - in terms of quantity and quality - cannot be controlled by the service provider. Also, a future shift away from HWS back to municipal supply (say after lifting restrictions) is likely in view of the unit cost of water, because supply from most HWS is considered relatively expensive compared to municipal supply. Water service planning is thus complicated by the introduction, and possible future decommissioning, of any HWS.

The significant reduction in water from piped reticulation systems with wide-scale introduction of HWS could be seen as an advantage in terms of a reduction in demand on the finite and costly potable stream. In contrast, wide-scale decommissioning of HWS would induce a substantial and unexpected load on the water distribution system.

Greywater reuse would reduce the load (quantity) on the sewer system and on wastewater treatment works. Reduced flows in sewers could lead to increased incidents of blockages and would lead to higher pollutant loads, because the relatively clean wastewater components would be specifically targeted for greywater reuse. Also wide-scale use of HWS could be a

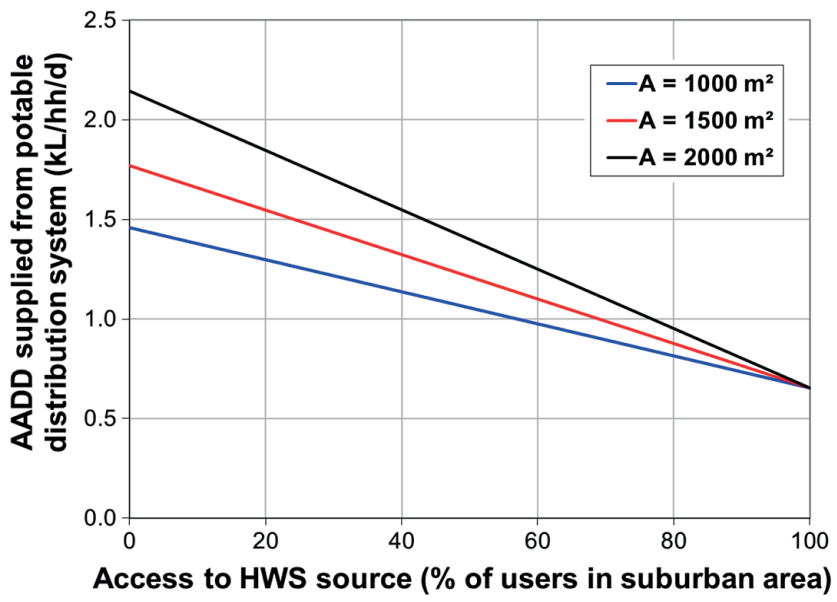

Figure 4

Modelled AADD for three property sizes with $100 \%$ of GI met by HWS 
concern in instances where analyses of data from consumer water meters is used for planning purposes, which may not accurately reflect the actual total water needs of residential consumers.

\section{CONCLUSION}

Supplementary household water sources are available, and are in use locally. This research included a comprehensive review of all supplementary household water sources currently available to consumers. The focus of subsequent analyses was on groundwater, rainwater and greywater. Consumers are faced with the challenge that South African legislation is unclear about the use of HWS, especially greywater, which may constitute health and environmental risks if used without treatment and disinfection. Earlier research has underlined that the use of any HWS, including greywater, is not specifically excluded by existing legislation. In terms of the legal implications, despite HWS not being dealt with directly in the NWA or the WSA, it could be concluded from this study that HWS for domestic purposes in a serviced area could be deemed 'legal' in the general case. No registration of the particular use is required, unless a municipality has followed procedures by which by-laws have been put in place, thus regulating the registration of such use - in such a case a homeowner may be required to register use of a HWS, with consequences if not registered. Another concern with HWS application is the non-potable water quality, associated risks and personal liability to manage the decentralised 'private' system, especially when it comes to greywater reuse (Carden et al., 2017). Maimon et al. (2010) note that '...the use of untreated greywater is not recommended due to associated risks, even for single households'. Despite a HWS being considered 'legal', consumers with HWS are not excluded from personal liability, which may arise for individual homeowners who make non-potable supplementary water available on the property.

The HWS end-use model described in this paper, and the subsequent results, are valuable in providing strategic direction in terms of water demand. Groundwater is the HWS considered to have the most notable penetration and intensity to impact potable water demand in residential areas, and is coupled to a relatively low risk in terms of water quality relative to (say) greywater reuse. On-site HWS commonly applied to meet garden irrigation demand could lead to a theoretical reduction of $55 \%$ (1 $000 \mathrm{~m}^{2}$ property) to $69 \%$ (2 $000 \mathrm{~m}^{2}$ property) in potable water use from the distribution system, when compared to the case with exclusive potable supply and a specific hypothetical baseline property in periods of unrestricted supply.

Additional research is required to determine what fraction of users would be likely to apply HWS, or are doing so already. Consumers often implement a HWS during periods of stringent water restrictions or under intermittent supply conditions. The number of people affected by intermittent water supply will most likely increase, because climate change, population growth, rising standards of living and rapid urbanisation causes increased pressure on potable water resources (Kumpel and Nelson, 2015). The links between a HWS, intermittent supply, relatively low system pressure and associated health risks need to be modelled and better understood. Potable water use at home typically reduces during stringent water restrictions (Jacobs et al., 2007) and also potentially under intermittent supply conditions, but community health risks increase due to reduced source water quality and reduced frequency of washing, as well as water sharing among family members (Fan et al., 2014).

On-site storage of water, often provided with a HWS, improves water supply system resilience from the viewpoint of the consumer, but the matter is complicated by the fact that the on-site storage is non-potable. The complex interaction between non-potable consumer supply and potable municipal supply, in terms of system resilience and reliability, is poorly understood - especially under conditions of intermittent supply or during system pressure violations.

While introduction of a HWS may improve the quantity of supply to an urban area by reducing the load on the potable water distribution system, the water quality of the entire system may be compromised in the process. Further research needs to address the matter of untreated supplementary water sources potentially becoming cross-connected to potable supply systems, which may lead to cross-contamination of potable supplies.

\section{ACKNOWLEDGEMENTS}

The research results presented in this report emanate from a project funded by the Water Research Commission, Project K5/1819, entitled 'Strategic assessment of household on-site water as supplementary resource to potable municipal supply - current trends and future needs'. The financing of the project by the Water Research Commission and the contribution of the members of the Steering Committee are gratefully acknowledged.

\section{REFERENCES}

BEAL CD, SHARMA A, GARDNER T and CHONG M (2012) A desktop analysis of potable water savings from internally plumbed rainwater tanks in south-east Queensland, Australia. Water Resour. Manage. 26 1577-1590. https://doi.org/10.1007/s11269-011-9973-0

BLAINE TW, CLAYTON S, ROBBINS P and GREWAL PS (2012) homeowner attitudes and practices towards residential landscape management in Ohio, USA. Environ. Manage. 50 257-271. https:// doi.org/10.1007/s00267-012-9874-x

BOTHA BE (2017) Estimating household groundwater abstraction by means of a probability model. Master's thesis, Stellenbosch University, South Africa. URL:http://scholar.sun.ac.za/ handle/10019.1/100900 (Accessed 24 August 2017).

CARDEN K, FISHER-JEFFES L, YOUNG, C, BARNES J and WINTER K (2017) Development of resource guidelines for greywater use and management - Guidelines for greywater use and management in South Africa. WRC Research Project K5/2592, Final report, April 2017. Water Research Commission, Pretoria.

CHRISTOVA-BOAL D, EDEN RE and MCFARLANE S (1996) An investigation into greywater reuse for urban residential properties. Desalination 106 391-397. https://doi.org/10.1016/ S0011-9164(96)00134-8

CITY OF CAPE TOWN (2017) Residential water restrictions explained - Level 4b water restrictions. URL: https://www.capetown.gov.za/ Family\%20and\%20home/residential-utility-services/ residentialwater-and-sanitation-services/2016-residential-water-restrictionsexplained (Accessed 31 July 2017).

CLAYTON S (2007) Domesticated nature: Motivations for gardening and perceptions of environmental impact. J. Environ. Psychol. 27 (3) 215-224. https://doi.org/10.1016/j.jenvp.2007.06.001

DOBROWKSY PH, MANNEL D, DE KWAADSTENIET M, PROZESKY H, KHAN W and CLOETE TE (2014) Quality assessment and primary uses of harvested rainwater in Kleinmond, South Africa. Water SA 40 (3) 401-406. https://doi.org/10.4314/wsa. v40i3.2

DORIA MF (2006) Bottled water versus tap water: understanding consumers' preferences. J. Water Health 4 (2) 271-276. 
ERIKSSON E, AUFFARTHN K, EILERSEN A-M, HENZE M and LEDIN A (2003) Household chemicals and personal care products as sources for xenobiotic organic compounds in grey wastewater. Water SA 29 (2) 135-146. https://doi.org/10.4314/wsa.v29i2.4848

FAN L, LIU G, WANG F, RITSEMA CJ and GEISSEN V (2014) Domestic water consumption under intermittent and continuous modes of water supply. Water Resour. Manage. 28 853-865. https:// doi.org/10.1007/s11269-014-0520-7

FISHER-JEFFES LN, ARMITAGE NP and CARDEN K (2017) The viability of domestic rainwater harvesting in the residential areas of the Liesbeek River Catchment, Cape Town. Water SA 43 (1) 81-90. https://doi.org/10.4314/wsa.v43il.11

GOVENDER T, BARNES JM and PIEPERCH (2011) Contribution of Water Pollution from Inadequate Sanitation and Housing Quality to Diarrheal Disease in Low-Cost Housing Settlements of Cape Town, South Africa. Am. J. Public Health 101 (7) e4-e9. https://doi. org/10.2105/AJPH.2010.300107

GREEN GC (1985) Estimated Irrigation Requirements of Crops in South Africa (Part1). Department of Agriculture and Water Supply, Soil and Irrigation Research Institute.

GROBICKI A and COHEN B (1999) Water reclamation for direct re-use in urban and industrial applications in South Africa and its projected impact upon water demand. WRC Report No. KV118/99. Water Research Commission, Pretoria.

ILEMOBADE AA, OLANREWAJU OO and GRIFFIOEN ML (2012) Greywater reuse for toilet flushing in high-density urban buildings in South Africa: a pilot study. WRC Report No. 1821/1/11. ISBN 978-1-4312-0213-3. Water Research Commission, Pretoria.

JACOBS HE and HAARHOFF J (2004a) Structure and data requirements of an end-use model or residential water demand and return flow. Water SA 30 (3) 293-304.

JACOBS HE and HAARHOFF J (2004b) Prioritisation of parameters influencing residential water use and wastewater flow. J. Water Suppl. Res. Technol. AQUA 56 (8) 495-514.

JACOBS HE, FAIR K, GEUSTYN LC, DANIELS J and DU PLESSIS JA (2007) Analysis of water savings: A Case study during the 2004-2005 water restrictions in Cape Town. J. S. Afr. Inst. Civ. Eng. 49 (3) 16-26.

JACOBS HE and VAN STADEN S (2008) Direct on-site greywater reuse - an illicit or illustrious option. WISA 2008 Biennial Conference and Exhibition, 18-22 May 2008, Sun City, South Africa.

JOHNSON EH (1987) Flow data acquisition and forecasting system for a water distribution network. Laureatus in Technology, Department Civil Engineering, Port Elizabeth Technikon.

KREYSIG D (1996) Greywater recycling: treatment techniques and cost savings. World Water and Environmental Engineering, Water Conservation and Recycling 19 (3) 18-19.
KUMPEL E and NELSON KL (2015) Intermittent water supply: prevalence, practice, and microbial water quality. Environ. Sci. Technol. 50 542-553. https://doi.org/10.1021/acs.est.5b03973

LINSLEY RK and FRANZINI JB (1979) Water Resources Engineering (3rd edn). McGraw-Hill, Blacklick, Ohio, USA.

MAIMON A, TAL A, FRIEDLER E and GROSS A (2010) Safe on-site reuse of greywater for irrigation - a critical review of current guidelines. Environ. Sci. Technol. 44 (9) 3213-3220. https://doi. org/10.1021/es902646g

MAKWIZA C, FUAMBA M, HOUSSA F AND JACOBS HE (in press) Estimating the impact of climate change on residential water use using panel data analysis: a case study of Lilongwe, Malawi. J. Water, Sanit. Hyg. Dev. (in press, Accepted July 2017).

MILNE M (1979) Residential Water Reuse. National Technical Information Service, Springfield, Davis Report No 46, Technical Completion Report Project UCAL-WRC-W-537, California Water Resources Center, September 1979. 553 pp.

MUKHEIBIR P, BOYLE T, MOY C and WHITE S (2014) Estimating the reliable residential water substitution from household rainwater tanks. Water Practice Technol. 9 (3) 377-385. https://doi. org/10.2166/wpt.2014.040

RSA (Republic of South Africa) (1997) Water Services Act (Act 108 of 1997). Government Gazette No. 1852219 December 1997.

RSA (Republic of South Africa) (1998) National Water Act (Act 36 of 1998). Government Gazette No. 1918226 August 1998.

RSA (Republic of South Africa) (2001) Water Services Act, 1997 Regulations relating to compulsory national standards and measures to conserve water. Government Gazette No. 223558 June 2001.

RODDA N, CARDEN K, ARMITAGE N and DU PLESSIS HM (2011) Development of guidance for sustainable irrigation use of greywater in gardens and small-scale agriculture in South Africa. Water SA 37 (5) 727-738. https://doi.org/10.4314/wsa.v37i5.10

WHO (World Health Organisation) (2006) Overview of greywater management. Health Considerations. Discussed and approved at the regional consultation on national priorities and plans of action on management and reuse of wastewater, Amman, Jordan. WHO-EM/CEH/125/E. WHO, Geneva.

WRIGHT T and JACOBS HE (2016) Potable water use of residential consumers in the Cape Town metropolitan area with access to groundwater as a supplementary household water source. Water SA 42 (1) 144-151. https://doi.org/10.4314/wsa.v42i1.14

ZEISEL J and NOLDE E (1995) Greywater recycling in urban areas. Proc. 2nd International Symposium on Wastewater Reclamation and Reuse, October 1995, 959-970. 